\title{
Correction: PDGFR $\alpha$ depletion attenuates glioblastoma stem cells features by modulation of STAT3, RB1 and multiple oncogenic signals
}

\section{Carlo Cenciarelli, Hany E. Marei, Armando Felsani, Patrizia Casalbore, Gigliola Sica, Maria Ausiliatrice Puglisi, Angus J.M. Cameron, Alessandro Olivi and Annunziato Mangiola}

Copyright: Cenciarelli et al. This is an open-access article distributed under the terms of the Creative Commons Attribution License (CC-BY), which permits unrestricted use, distribution, and reproduction in any medium, provided the original author and source are credited.

Present: Reference and callout information were presented incorrectly for reference 24 .

Correct: The proper reference and callout information are listed below.

\section{RESULTS}

Cancer stem cells from GBM were isolated as described previously [24]. We were able to collect either core- (c-CSC) or peritumor tissue-derived cancer stem cells ( $\mathrm{p}$-CSC) from several primary GBM samples. The two types of CSC form intracranial tumors in immunocompromised mice. Nevertheless, c-CSC showed a higher tumor initiating ability when compared with p-CSC which had a lower tumorigenicity [24].

\section{REFERENCES}

24. Lama G, Mangiola A, Proietti G, Colabianchi A, Angelucci C, D’Alessio A, De Bonis P, Geloso MC, Lauriola L, Binda E, Biamonte F, Giuffrida MG, Vescovi A, Sica G. Progenitor/Stem Cell Markers in Brain Adjacent to Glioblastoma: GD3 Ganglioside and NG2 Proteoglycan Expression. J Neuropathol Exp Neurol. 2016; 75:134-47.

Original article: Oncotarget. 2016; 7:53047-53063. doi: 10.18632/oncotarget.10132 